\title{
Dynamics of Intracellular Free Calcium Concentration in the Presynaptic Arbors of Individual Barnacle Photoreceptors
}

\author{
Joseph C. Callaway, ${ }^{1,2}$ Nechama Lasser-Ross, ${ }^{2}$ Ann E. Stuart, ${ }^{1}$ and William N. Ross ${ }^{2}$ \\ 'Department of Physiology, University of North Carolina at Chapel Hill, Chapel Hill, North Carolina 27599 and ${ }^{2}$ Department \\ of Physiology, New York Medical College, Valhalla, New York 10595 and The Marine Biological Laboratory, Woods Hole, \\ Massachusetts 02543
}

At photoreceptor synapses, transmitter release is continuous and graded. At this type of synapse, the control of pre-

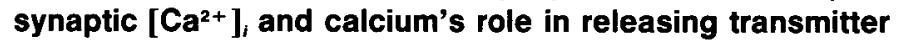
might be different than at terminals invaded by all-or-none action potentials. To examine this possibility, we measured the spatial and temporal changes of $\left[\mathrm{Ca}^{2+}\right]_{i}$ in response to depolarization of individual photoreceptor terminals of the barnacle Balanus nubilus, which had been injected with the $\mathrm{Ca}^{2+}$ indicator Fura-2. Depolarizing pulses produced voltage-dependent $\mathrm{Ca}^{2+}$ entry that was confined to the tips of the arbor where the release sites are located. At increasing distances from the tips, the rate of $\left[\mathrm{Ca}^{2+}\right]_{i}$ increase was slower and the peak $\left[\mathrm{Ca}^{2+}\right]_{i}$ occurred later, suggesting that $\mathrm{Ca}^{2+}$ entered the tips and diffused back into the larger processes of the arbor. Consistent with this result, a stable gradient of $\left[\mathrm{Ca}^{2+}\right]$, was observed at maintained depolarizations, with the highest values at the tips of the arbor. Removal of external $\mathrm{Na}^{+}$did not affect the time course of $\mathrm{Ca}^{2+}$ decline in the terminal, indicating that $\mathrm{Na}^{+} / \mathrm{Ca}^{2+} \mathrm{ex}-$ change was not the primary mechanism for restoring $\left[\mathrm{Ca}^{2+}\right]_{i}$ to basal levels. Computer simulations, assuming only $\mathrm{Ca}^{2+}$ entry at the arbor's tips and diffusion of $\mathrm{Ca}^{2+}$ away from the entry site, qualitatively reproduced these observations. The threshold for $\mathrm{Ca}^{2+}$ entry was near $-60 \mathrm{mV}$, and entry was maintained during prolonged depolarizations, in agreement with previous experiments showing that $\mathrm{Ca}^{2+}$ channels in the terminal region do not inactivate. The time course of the measured $\left[\mathrm{Ca}^{2+}\right]_{i}$ change in the terminal paralleled voltage changes due to a $\mathrm{Ca}^{2+}$-activated $\mathrm{K}+$ conductance, which senses $\left[\mathrm{Ca}^{2+}\right]_{i}$ just under the membrane. This parallelism is expected since the release sites are located on processes of small-enough diameter to permit radial equilibration of $\left[\mathrm{Ca}^{2+}\right]$, within the time course of physiological voltage changes. Therefore, the optical measurements reflect the mean level of $\left[\mathrm{Ca}^{2+}\right]$, under the membrane. Whether this mean concentration is also the value at the sites that trigger exocytosis will depend on how close the $\mathrm{Ca}^{2+}$ channels are to these sites.

\footnotetext{
Received June 10, 1992; revised Sept. 14, 1992; accepted Sept. 22, 1992.

This work was supported in part by U.S. Public Health Service Grants NS16295 to W.N.R. and EY03347 to A.E.S., and by a Marine Biological Laboratory M.G.F. Fuortes fellowship to J.C.C.

Correspondence should be addressed to Ann E. Stuart, Department of Physiology, CB\#7545, University of North Carolina at Chapel Hill, Chapel Hill, NC 27599-7545.

Copyright (C) 1993 Society for Neuroscience $0270-6474 / 93 / 131157-10 \$ 05.00 / 0$
}

[Key words: Fura-2, calcium, photoreceptor, synapse, barnacle, diffusion]

Our understanding of the secretion of nonpeptide, fast-acting transmitters is based primarily on observations at terminals invaded by action potentials. Here, at the active zone, $\mathrm{Ca}^{2+}$ channels are thought to be closely associated with intracellular $\mathrm{Ca}^{2+}$ receptors responsible for triggering exocytosis. Their close proximity enables $\mathrm{Ca}^{2+}$ entering during an action potential to raise the calcium concentration, $\left[\mathrm{Ca}^{2+}\right]_{i}$, rapidly to a high level (possibly greater than $100 \mu \mathrm{M}$ ), leading to rapid release (Smith and Augustine, 1988; Roberts et al., 1990; Thomas et al., 1990; Adler et al., 1991; Verhage et al., 1991). Following the presynaptic action potential, the localized peak $\left[\mathrm{Ca}^{2+}\right]_{i}$ quickly declines, although the $\left[\mathrm{Ca}^{2+}\right]_{i}$ in the bulk cytoplasm remains clcvated for seconds (Charlton et al., 1982).

The pattern of changes in $\left[\mathrm{Ca}^{2+}\right]_{i}$ may be different at the presynaptic terminals of photoreceptors. These cells continuously release transmitter, modulating this release with small, graded changes in membrane potential (Cervetto and Piccolino, 1974; Hayashi et al., 1985; Attwell, 1986). Electrophysiological evidence suggests that $\mathrm{Ca}^{2+}$ enters the release zone steadily when the cell is continuously depolarized. This notion is consistent with evidence that shows that $\mathrm{Ca}^{2+}$ channels in photoreceptors inactivate very slowly if at all (Corey et al., 1984; Stuart et al., 1986; Barnes and Hille, 1989). For these reasons, photoreceptors might not have such large and rapidly changing gradients in $\left[\mathrm{Ca}^{2+}\right]_{i}$ at the release sites as occur during action potentials.

To investigate these issues, we measured the spatiotemporal changes of $\left[\mathrm{Ca}^{2+}\right]_{i}$ in the presynaptic arbors of individual photoreceptors of the giant barnacle in response to transient and sustained depolarizations. Barnacle photoreceptors were selected because the large size of the presynaptic axon and the anatomy of the terminal region (Hudspeth and Stuart, 1977; Schnapp and Stuart, 1983) allow the presynaptic voltage to be recorded and controlled while measuring spatially resolved $\left[\mathrm{Ca}^{2+}\right]_{i}$ changes with optical techniques.

Previously, localized $\mathrm{Ca}^{2+}$ entry into the terminal region was detected in this preparation by injecting the $\mathrm{Ca}^{2+}$ indicator arsenazo III into individual photoreceptors and measuring absorbance changes of this indicator with a photodiode array in response to depolarization of the terminal region (Stockbridge and Ross, 1984). In the present experiments, we injected the more sensitive dye Fura-2 (Grynkiewicz et al., 1985) and detected changes in fluorescence, corresponding to changes in $\left[\mathrm{Ca}^{2+}\right]_{i}$, with a more versatile cooled CCD camera (Connor, 
1986) operated at high frame rates (Lasser-Ross et al., 1991a). These improvements enabled us to make measurements with greater accuracy and higher spatial resolution and for longer times than the previous ones. Consequently, we were able to establish that $\mathrm{Ca}^{2+}$ steadily enters the terminal region when the membrane is depolarized and is removed largely by diffusion into the larger axonal processes.

Aspects of this work have been reported in abstract form (Callaway et al., 1990; Lasser-Ross et al., 1991a; Stuart et al., 1991).

\section{Materials and Methods}

Preparation, intracellular recording, and dye injection. Experiments were performed on the median photoreceptors from the giant barnacle ( $\mathrm{Bal}$ anus nubilus). Animals were obtained from Bio-Marine Enterprises (Seattle, WA) and maintained at about $10^{\circ} \mathrm{C}$ in fresh seawater at the Marine Biological Laboratory. Preparations consisting of the median ocellus and median ocellar nerve, containing the axons of the four median photoreceptors and supraesophageal ganglion to which they project, were dissected as described in Hudspeth and Stuart (1977). Just prior to electrode impalement, the ocellus was cut off about $5 \mathrm{~mm}$ from the ganglion so that the measuring light would not be detected by the photoreceptors.

Normal saline contained $461.5 \mathrm{~mm} \mathrm{NaCl}, 8 \mathrm{~mm} \mathrm{KCl,} 20 \mathrm{~mm} \mathrm{CaCl}$, $12 \mathrm{mM} \mathrm{MgCl}_{2}$, and $10 \mathrm{~mm}$ Tris (hydroxymethyl) aminomethane- $\mathrm{HCl}$ buffer at $\mathrm{pH}$ 7.7. For saline used to block $\mathrm{Ca}^{2+}$ entry, $17 \mathrm{~mm} \mathrm{CoCl}_{2}$ and $3 \mathrm{~mm} \mathrm{CaCl}_{2}$ replaced the $20 \mathrm{~mm} \mathrm{CaCl}_{2}$ in normal saline. For $\mathrm{Na}$-free salines, equimolar amounts of choline chloride or $N$-methyl glucamine replaced the $461.5 \mathrm{mM} \mathrm{NaCl}$ in normal saline.

Preparations were pinned ventral surface up in a Sylgard (Dow-Corning)-lined chamber, placed on the stage of an upright Zeiss Universal Microscope, and superfused with saline at $11^{\circ} \mathrm{C}$ at roughly $1 \mathrm{ml} / \mathrm{min}$. The recording chamber and objective lens were also cooled by a circulating refrigerant. Microelectrodes were pulled on a Brown-Flaming puller (Sutter Instruments) from $1.2 \mathrm{~mm}$ o.d. capillary glass (\#1011-I, Glass Co. of America, Bargaintown, $\mathrm{NJ}$ ) and had resistances of 50-70 $\mathrm{M} \Omega$ when the tips were filled with 6 or $12 \mathrm{~mm}$ Fura-2 free acid (\#F1200 , Molecular Probes, Eugene, OR) dissolved in $0.2 M \mathrm{~K}$-acetate and the shanks backfilled with $4 \mathrm{M} \mathrm{K}$-acetate.

The four photoreceptors whose somata and rhabdomeric dendrites comprise the median eye typically extend their axons $1 \mathrm{~cm}$ to their targets in the supraesophageal ganglion. As they enter this ganglion on the midline, they bifurcate, each primary process extending from 20 $\mu \mathrm{m}$ to $100 \mu \mathrm{m}$ into each hemiganglion. Here they branch into a spray of smaller secondary and tertiary processes forming a compact arbor. Electron micrographs through this arbor show that the active zones are located on photoreceptor profiles $1-4 \mu \mathrm{m}$ in diameter (Schnapp and Stuart, 1983). The region of ganglion containing this terminal arbor was viewed with a $25 \times$ water-immersion objective (\#619706, I eitz; $0.6 \mathrm{NA}$, $1.2 \mathrm{~mm}$ working distance) for impalement with the microelectrode and for optical measurements. Photoreceptors were impaled in their axons just proximal (toward the soma) to the bifurcation or in a primary process just distal to it. Fura-2 was injected iontophoretically with steady hyperpolarizing current (1-2 nA) until the arbors were filled (about 20 min). The terminals were viewed periodically with fluorescence optics to monitor the progress of the filling. Following the injection, one of the two arbors was selected for optical measurements and positioned within the optical field of the CCD camera. The dye-filled electrode was used throughout the experiment to measure and control the membrane potential. Since the cell has a very large space constant (Hudspeth et al., 1977), the potential at the recording site is probably close to the potential in the terminal region. The membrane potential was set with a single electrode current clamp (Axoclamp 2A, Axon Instruments) using a switching frequency of $500 \mathrm{~Hz}$. Due to the long time constant of these cells, this rate was sufficient to follow the slow potential changes in the terminal processes.

$\left[\mathrm{Ca}^{2+}\right]_{\mathrm{i}}$ measurements. Fluorescence recordings were made with a high-speed CCD imaging system (Lasser-Ross et al., 1991b). The camera was controlled by a PC/AT computer that recorded image sequences concurrently with changes in membrane potential. For measuring rapid changes of $\left[\mathrm{Ca}^{2+}\right]_{i}$, Fura-2 was excited with a single wavelength of light $(380 \mathrm{~nm}, 10 \mathrm{~nm}$ half-width), and the emitted fluorescence was detected at wavelengths longer than $495 \mathrm{~nm}$. The light intensity (from a $75 \mathrm{~W}$ xenon arc lamp) was attenuated to reduce bleaching of the dye to less than $1 \%$ in $5 \mathrm{sec}$. We typically took 40 frames per second of $50 \times 50$ element images, each element consisting of a small rectangular array of pixels. Some measurements were made at 100 frames per second (18 $\times 18$ element images) to increase time resolution, and others at 20 frames per second $(100 \times 100$ element images $)$ to increase spatial resolution.

The change in fluorescence $(\Delta F)$ at a given locus was determined as the difference between the measured fluorescence and the fluorescence at that locus at the resting potential $(F)$ at a time prior to any stimulus. For measurements at $380 \mathrm{~nm}, \Delta F$ is negative when $\left[\mathrm{Ca}^{2+}\right]_{i}$ increases (Grynkiewicz et al., 1985), so a decrease in fluorescence is plotted upward in all figures to correspond to increasing $\left[\mathrm{Ca}^{2+}\right]_{i}$. This decrease was typically divided by the resting fluorescence $(F)$, which had been corrected for autofluorescence, to obtain the fractional fluorescence change, $\Delta F / F$. In principle this ratio can be converted to $\Delta\left[\mathrm{Ca}^{2+}\right]_{i}$ by the formula

$$
\Delta[\mathrm{Ca}]_{i}=\frac{[\mathrm{Ca}]_{\mathrm{rest}}+K_{d} \times(\Delta F / F) /(\Delta F / F)_{\max }}{1-(\Delta F / F) /(\Delta F / F)_{\max }}-[\mathrm{Ca}]_{\mathrm{rest}}
$$

where $\left[\mathrm{Ca}^{2+}\right]_{\mathrm{rest}}$ is the $\left[\mathrm{Ca}^{2+}\right]_{i}$ at resting potential, $K_{d}$ is the $\mathrm{Ca}^{2+}:$ Fura-2 dissociation constant, and $(\Delta F / F)_{\max }$ is the maximum possible change at high $\left.\mathrm{Caa}^{2+}\right]_{i}$ (about 0.75 for these experiments). This formula shows that $\left[\mathrm{Ca}^{2+}\right]_{i}$ is a monotonically increasing function of $\Delta F / F$. The results were left in the ratio form since the relative magnitudes and the time courses of the changes contained the physiologically relevant information, and because the value for $\left[\mathrm{Ca}^{2+}\right]_{\text {rest }}$ was not determined for each experiment.

The steady state $\left[\mathrm{Ca}^{2+}\right]_{i}$ levels were determined by the ratio method (Grynkiewicz et al., 1985; Lev-Ram et al., 1992) from the formula

$$
\left[\mathrm{Ca}^{2+}\right]_{i}=K_{d} \cdot\left(R-R_{\min }\right) /\left(R_{\max }-R\right) \cdot\left(S_{12} / S_{\mathrm{b} 2}\right),
$$

where $R=350: 380$ intensity ratio, $R_{\min }=0.289, R_{\max }=4.79, S_{\mathrm{R}} / S_{\mathrm{b} 2}$ $=12.0$ (our measurements), and $K_{d}=450 \mathrm{~nm}$ (Blumenfeld et al., 1990). A viscosity correction of 0.15 was applied.

Voltage changes in the terminal region in response to direct illumination of the terminal membrane. Very bright illumination of the terminals of these photoreceptors can sometimes evoke voltage changes even when the cell soma with its rhabdomeric dendrites has been cut off(Edgington and Stuart, 1992). We occasionally encountered terminals in which the measuring light evoked a depolarization and an increase in $\left[\mathrm{Ca}^{2+}\right]_{i}$. This light-induced $\mathrm{Ca}^{2+}$ signal was summed with the $\mathrm{Ca}^{2+}$ signal evoked by depolarizing the terminal with current, and it was not possible to separate the two. Therefore, none of the experiments where a $\left[\mathrm{Ca}^{2+}\right]_{i}$ change was evoked by the excitation light werc included in this article.

\section{Results}

Time course and spatial distribution of the Fura-2 signals. We filled the presynaptic arbors of 12 photoreceptors with Fura-2 and observed changes in fluorescence in response to voltage changes caused by current injected through the microelectrode. Figure $1 A$ is an image taken with the CCD camera of one of these arbors impaled with a microelectrode in the axon (open bracket) just before its first bifurcation. This particular arbor is asymmetric, the left primary process extending about three times the distance of that on the right; a second left-hand primary process of small diameter (arrows) parallels the larger one. Bushes of secondary and tertiary processes (closed brackets) housing the release sites spray abruptly from these primary processes. The "spray" occupies roughly the distalmost $50 \mu \mathrm{m}$ of each side. The arbor of Figure $1 A$ is used to illustrate many of the observations in this article because it was in focus over a large area and all of its processes fit into the field of view.

Depolarization of a barnacle photoreceptor's arbor is known to cause an inward $\mathrm{Ca}^{2+}$ current across the presynaptic membrane (Ross and Stuart, 1978; Stuart et al., 1986). When pulses of depolarizing current were injected through the microelectrode, they led to a rapid, monotonic increase in $\left[\mathrm{Ca}^{2+}\right]_{i}$ (Fig. 

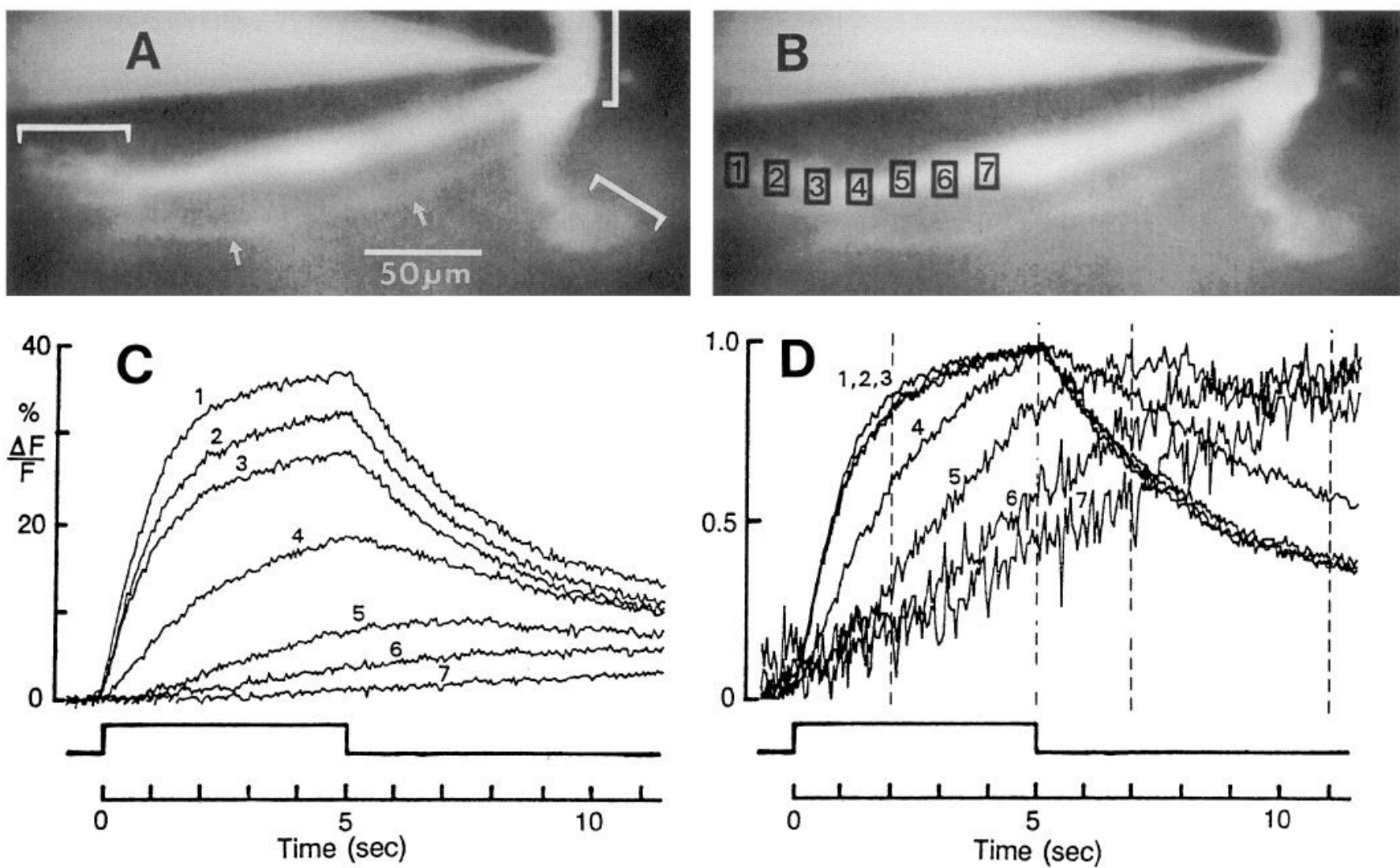

Figure 1. Change in $\left[\mathrm{Ca}^{2+}\right]_{i}$ in the photoreceptor's presynaptic arbor in response to depolarizing current pulses. $A$, Digital fluorescence photograph of Fura-2-filled arbor. The Fura-2-filled microelectrode impaled the cell from the upper left. Closed brackets delimit terminal regions; open bracket marks the axon. $B$, Seven boxes are drawn on the arbor shown in $A$ and numbered to correspond to the seven traces in $C$ and $D$. Boxes are $8 \times 12$ $\mu \mathrm{m}^{2}$. $C$, Average $\Delta F / F$ as a function of time (numbered traces) within each of the seven boxes (shown in $B$ ) corresponding to the voltage change caused by a $5 \mathrm{sec}$ depolarizing current pulse. Images were captured every $50 \mathrm{msec}$ by a $40 \times 70$ array of bins, each approximately $4 \times 4 \mu \mathrm{m}^{2}(16$ pixels per bin). The ordinate $(\Delta F / F)$ is related to the change in free $\left[\mathrm{Ca}^{2+}\right]_{i}$ as described in Materials and Methods. In the distal portion of the arbor (boxes $1-3$ ), the $\left[\mathrm{Ca}^{2+}\right]$, rose steadily, approaching a plateau, and then decreased immediately at the offset of the pulse. In the more proximal region of the primary branch (boxes 4-7), $\left[\mathrm{Ca}^{2+}\right]_{i}$ rose to lower values and continued to rise at the offset of the pulse. $D$, Traces shown in $C$ normalized to peak levels for each trace. The four broken lines at 2, 5, 7, and $11 \mathrm{sec}$ indicate time points at which pseudocolor images of the [Ca $\left.{ }^{2+}\right]_{i} \mathrm{changes}^{2}$ from rest in the arbor are shown in Figure $2 A$.

1). The amplitude of the $\left[\mathrm{Ca}^{2+}\right]_{i}$ change was markedly reduced when preparations were bathed in saline containing $\mathrm{Co}^{2+}$ and reduced $\mathrm{Ca}^{2+}$ (not shown). In Figure $1 C$, we plot the change in $\Delta F / F$ as a function of time at each of seven locations along the left arbor (Fig. $1 B$ ) in response to a $5 \mathrm{sec}$ depolarizing pulse. Each trace shows the average change in $\Delta F / F$ versus time within each of the correspondingly numbered boxes. Boxes 1-3 are all from the spray of secondary and tertiary branches, and boxes 4-7 are placed on the primary, unbranched process.

In the spray, the $\left[\mathrm{Ca}^{2+}\right]_{i}$ rose sharply and steadily in response to the depolarization and approached a plateau value within several seconds. Upon repolarization, $\left[\mathrm{Ca}^{2+}\right]_{i}$ in the spray immediately began to decline. In the boxes positioned over the primary processes (boxes $4-7$ ), the rise in $\left[\mathrm{Ca}^{2+}\right]_{i}$ was considerably delayed, with a slower rise time than in the locations over the spray. Indeed, at the offset of the pulse the $\left[\mathrm{Ca}^{2+}\right]_{i}$ at loci along the primary process actually continued to rise to a lingering peak instead of immediately declining as it did in the spray. These different time courses are emphasized by replotting these traces with normalized peak amplitudes (Fig. $1 D$ ).

Figure $2 A$ is a different presentation of the results from the same experiment where the emphasis is on the spatial distribution of the $\mathrm{Ca}^{2+}$ signal. Here $\left[\mathrm{Ca}^{2+}\right]_{i}$ at each location is rep- resented by a $\Delta F / F$ value on a pseudocolor scale. The four images shown in this figure represent changes at 2, 5, 7, and 11 sec after the onset of the pulse. It is clear that the $\left[\mathrm{Ca}^{2+}\right]_{i}$ initially rose at the tips of the arbor, stayed high there for the duration of the $5 \mathrm{sec}$ pulse, and only later rose at more upstream locations.

The simplest interpretation of these observations is that depolarization causes an influx of $\mathrm{Ca}^{2+}$ (Ross and Stuart, 1978; Stockbridge and Ross, 1984) into the arbor primarily at the transmitter release sites on the arbor's tips. The $\mathrm{Ca}^{2+}$ then diffuses longitudinally within the arbor, resulting in a slower rise and fall of $\left[\mathrm{Ca}^{2+}\right]_{i}$ in the primary process. Simulations of the dynamics of $\left[\mathrm{Ca}^{2+}\right]_{i}$ assuming only entry at the tips and diffusion back along the primary process are consistent with this hypothesis (see Discussion).

Time course of decline of the Fura-2 signal. At the offset of the depolarizing pulse, the decline in the $\left[\mathrm{Ca}^{2+}\right]_{i}$ at the tips of the arbor was quasi-exponential (Fig. $1 C$ ). The rate of fall did not vary with pulse length or pulse amplitude within a given experiment, consistent with removal of the $\mathrm{Ca}^{2+}$ by diffusion. However, the time taken to fall to two-thirds of the final value ranged from 1 to $2.3 \mathrm{sec}$ within the group of cells studied. Some of this variability may have been due to buffering by different concentrations of Fura-2 in the terminal (Baylor and Holling- 


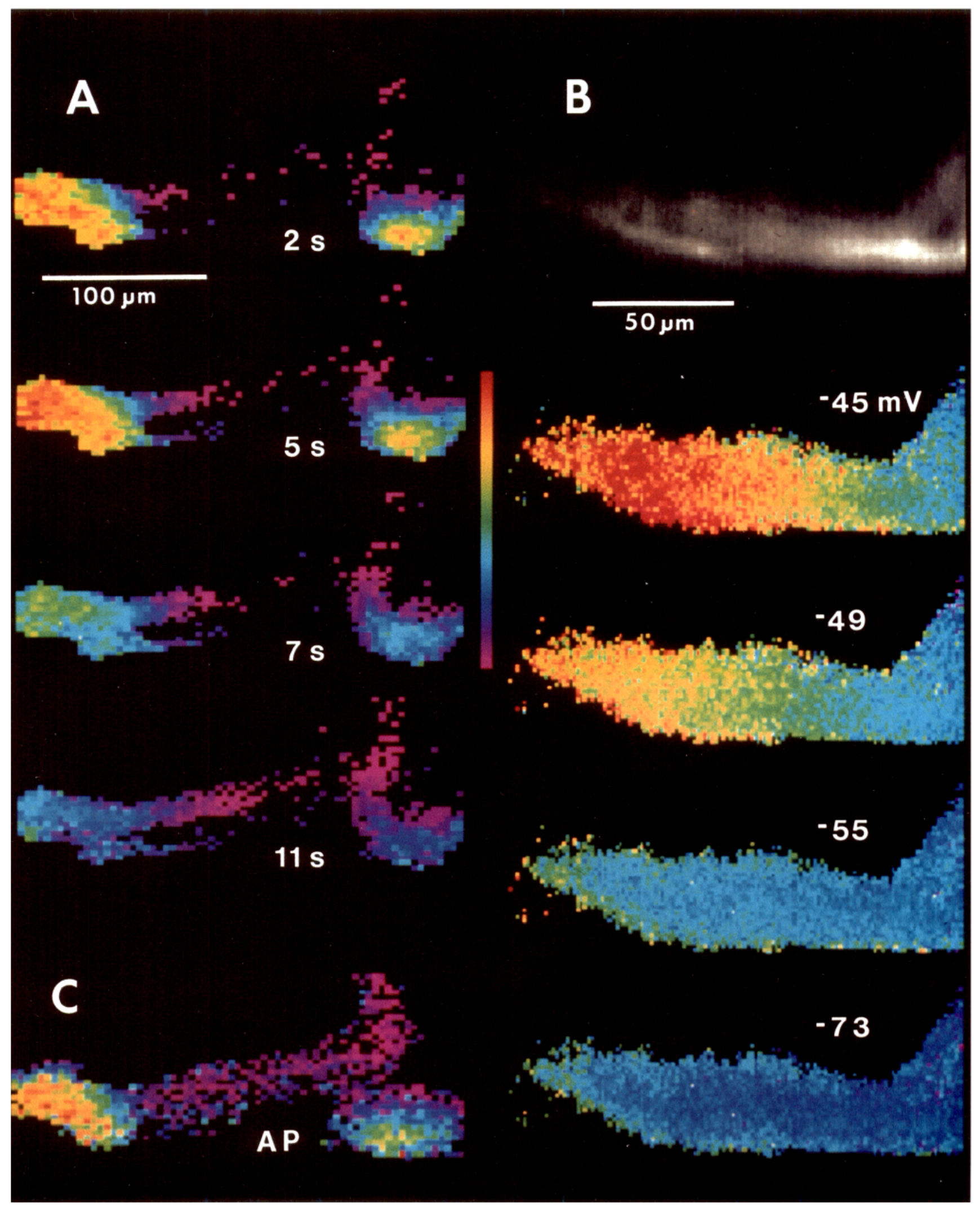

Figure 2. Pseudocolor images of $\left[\mathrm{Ca}^{2+}\right]_{i}$ distribution in the presynaptic arbor. $A$, Spatial profiles of the increase in $\left[\mathrm{Ca}^{2+}\right]_{i}$ from rest at four times (indicated by broken lines on Fig. $1 D$ ) during and after a $5 \mathrm{sec}$ depolarizing current pulse (data of Fig. $1 C, D$ ). The $s c a l e$ of colors represents $\Delta F / F$ ranging from $0 \%$ (violet) at the bottom to $40 \%$ at the top (red). Each image shows the difference between the [Ca $\left.{ }^{2+}\right]_{i}$ level at the time indicated below the image and the level before the beginning of the pulse. $B$, Steady state distributions of $\left[\mathrm{Ca}^{2+}\right]_{i}$ at four holding potentials in a different cell. Cell was held at each potential 2-3 min before measurement was made. Digital photograph (top) of a Fura-2-filled arbor and pseudocolor representations (four images below) of $\left[\mathrm{Ca}^{2+}\right]_{i}$ were determined by the ratio method (see Materials and Methods) in this arbor at the four holding 
worth, 1988). The rate of fall was not altered in $\mathrm{Na}^{+}$-free salines, suggesting that it was not significantly affected by a $\mathrm{Na}^{+} / \mathrm{Ca}^{2+}$ exchanger.

Steady state $\left[\mathrm{Ca}^{2+}\right]_{\mathrm{i}}$ gradients as a function of membrane potential. When the arbor was held depolarized for minutes, such as it would be during steady illumination, we observed stable gradients of $\left[\mathrm{Ca}^{2+}\right]_{i}$ extending along the arbor well into the primary process. Figure $2 B$ shows a set of these gradients at four different membrane potentials. As the membrane potential was held at more depolarized values, the gradient of $\left[\mathrm{Ca}^{2+}\right]_{i}$ became increasingly distinct. The threshold for the increase in $\left[\mathrm{Ca}^{2+}\right]_{i}$ appears to lie between $-73 \mathrm{mV}$ and $-55 \mathrm{mV}$ in this cell. At the most negative potential, $\left[\mathrm{Ca}^{2+}\right]_{i}$ was almost uniform throughout the terminal and axon and was calculated to be about 100 nм (see Fig. 2 caption). Continuous depolarization increased this value into the several hundred nanomolar concentration range.

Increase in $/ \mathrm{Ca}^{2+} J_{\mathrm{i}}$ during calcium action potentials. Previous evidence has indicated that $\mathrm{Ca}^{2+}$ channels are present not only at the tips of the photoreceptor arbors but also, at lower density, in nonsynaptic membrane (Edgington and Stuart, 1979). We tricd to detect direct $\mathrm{Ca}^{3+}$ entry into the primary processes and axon with large current pulses. However, we could not normally elicit a large-enough depolarization to detect such a signal because the membrane contains a rapidly activating, voltage-sensitive outward conductance. Blocking this conductance with tetraethylammonium ion (TEA) permits depolarizing current to elicit large and rapidly rising $\mathrm{Ca}^{2+}$-dependent action potentials (Ross and Stuart, 1978). Figure $2 C$ shows the spatial gradient of the Fura-2 signal at the peak of a $\mathrm{Ca}^{2+}$-dependent action potential evoked in saline containing $10 \mathrm{~mm}$ TEA. The $\left[\mathrm{Ca}^{2+}\right]_{i}$ at the peak of this $80 \mathrm{msec}$ action potential was greatest at the tips, but was also significant along the primary process and in the axon during this event. When the arbor was depolarized in the absence of TEA, a comparable concentration was not achieved until $11 \mathrm{sec}$ after the onset of the pulse when $\mathrm{Ca}^{2+}$ had diffused upstream from the tips (Fig. $2 A$ ).

The timc coursc of the change in $\left[\mathrm{Ca}^{2+}\right]_{i}$ during a $\mathrm{Ca}^{2+}$ action potential at selected locations along two different arbors is illustrated in Figure 3. Although the $\left[\mathrm{Ca}^{2+}\right]_{i}$ increase was fastest and greatest at the tips of each arbor (box 1), fast $\left[\mathrm{Ca}^{2+}\right]_{i}$ jumps were also detected in the primary branches and axon. This was not the case when the cell was simply depolarized with current (Fig. $1 B, D$ ). To effect such an immediate increase in $\left[\mathrm{Ca}^{2+}\right]_{i}$, $\mathrm{Ca}^{2+}$ must have entered the primary processes directly during the action potential.

The peak amplitudes of the $\left[\mathrm{Ca}^{2+}\right]$, signals during the action potential were similar at different locations along the primary process (see traces 5 and 6 in Fig. $3 B$ ). Since the diameter of the primary process is relatively constant, this result suggests a uniform or slowly changing density of $\mathrm{Ca}^{2+}$ channels in the membrane of the process. A signal may be detected even in the axon above the bifurcation (Fig. $3 B$, trace 7 ), supporting the conclusion that $\mathrm{Ca}^{2+}$ channels are present in the axonal $\mathrm{mcm}$ brane (Edgington and Stuart, 1979). We also note that the Fura-2 signals at loci along the primary processes either developed a hump after several seconds (Fig. $3 B$, traces 3 and 4 ) or were sustained (Fig. $3 B$, traces $5-7 ; E$, trace 4 ), presumably reflecting the retrograde diffusion of $\mathrm{Ca}^{2+}$ into this region from the tips in addition to direct entry at that site during the action potential.

The relationship between the Fura- 2 signal and the undershoot of the $\mathrm{Ca}^{2+}$-dependent action potential. To understand the relationship between $\left[\mathrm{Ca}^{2+}\right]_{i}$ and the release of transmitter, it is necessary to know the $\left[\mathrm{Ca}^{2+}\right]_{i}$, and how it changes with time, at the precise position under the membrane where the molecules involved in this process are located. As a first step toward this exacting goal, we asked whether the time course of the mean $\left[\mathrm{Ca}^{2}\right]_{i}$ reflected in our optical measurements corresponds to that of the submembrane $\left[\mathrm{Ca}^{2+}\right]_{i}$ as measured by the $\mathrm{Ca}^{2+}$. activated $\mathrm{K}^{+}$conductance present in these arbors (Edgington and Stuart, 1981). We assume that this conductance senses the $\left[\mathrm{Ca}^{2+}\right]_{i}$ at the inner surface of the $\mathrm{K}^{+}$channel but make no assumptions about the location of these channels with respect to the $\mathrm{Ca}^{2+}$ channels.

The $\mathrm{Ca}^{2+}$-activated $\mathrm{K}^{+}$conductance generates a prolonged undershoot following $\mathrm{Ca}^{2+}$-dependent action potentials; we compared the time course of this undershoot with that of the Fura-2 signal recorded at the same time (Fig. 4). Undershoots and Fura-2 signals of increasing duration were generated by increasing the [TEA] (from 10 to 50 and then to $100 \mathrm{~mm}$ ).

During the undershoot, the membrane is hyperpolarized and the $\mathrm{Ca}^{2+}$ channels are closed. Therefore, there should not be punctate zones of high $\left[\mathrm{Ca}^{2+}\right]_{i}$ at the mouths of the $\mathrm{Ca}^{2+}$ channels during this period. Furthermore, because of the slow time course of the afterhyperpolarization, we expect any local gradients set up under the membrane to have dissipated. Because the diameter of the processes on which the release sites are located is relatively small, radial equilibrium should also be achieved during this time (Stockbridge and Ross, 1984), and thus one might expect the bulk $\left[\mathrm{Ca}^{2+}\right]_{i}$ to reflect submembrane $\left[\mathrm{Ca}^{2+}\right]$.

In previous experiments, the undershoot had a time course similar to that of the change in arsenazo III absorbance measured simultaneously (Stockbridge and Ross, 1984). Figure 4 agrees with and extends these results. As the [TEA] was increased, the durations of the action potential and its undershoot (Fig. 4, bottom traces) and of the Fura-2 signal (Fig. 4, top traces) both increased. A comparison of the top and bottom traces of Figure 4 shows that there is an approximate, but not precise, correspondence between the time courses of the Fura-2 signals and the undershoots. The inaccuracy of the match might be due to several factors: the amplitude and time course of the undershoot will not be proportional to the underlying conductance change as the voltage approaches the $\mathrm{K}^{+}$equilibrium potential; the $\Delta F / F$ signal will not be linearly related to $\Delta\left[\mathrm{Ca}^{2+}\right]_{i}$ as the Fura-2 becomes saturated by $\mathrm{Ca}^{2+}$; the Hill coefficient for the $\mathrm{Ca}^{2+}$-activated $\mathrm{K}^{+}$channels might be greater than 1 . Nevertheless, these and the previous results using arsenazo III suggest that the average $\left[\mathrm{Ca}^{2+}\right]_{i}$ in the terminals tracks to a first approximation the concentration directly under the membrane where the $\mathrm{Ca}^{2+}$-activated conductance is controlled.

potentials indicated above each image. Each pixel in the image is a $5 \times 5 \mu \mathrm{m}^{2}$ array of elements, each $1 \mu \mathrm{m}^{2}$. The color scale represents a [Ca $\left.{ }^{2+}\right]$ range from $0 \mathrm{~nm}$ to $780 \mathrm{~nm}$. These values were calculated assuming a $K_{d}$ of $450 \mathrm{~nm}$ (Blumenfeld et al., 1990). $C$, Pseudocolor representation of the $\left[\mathrm{Ca}^{2+}\right]_{i}$ at the peak of an action potential $(A P$; duration, $80 \mathrm{msec})$ elicited in $10 \mathrm{~mm}$ TEA in the preparation shown in $A$. Since the $\left[\mathrm{Ca}^{2+}\right]_{i}$ rose to a higher value during the action potential than during step depolarizations, the color scale is different than in $A$, ranging from $0 \% \Delta F / F$ at the bottom to $75 \% \Delta F / F$ at the top. 

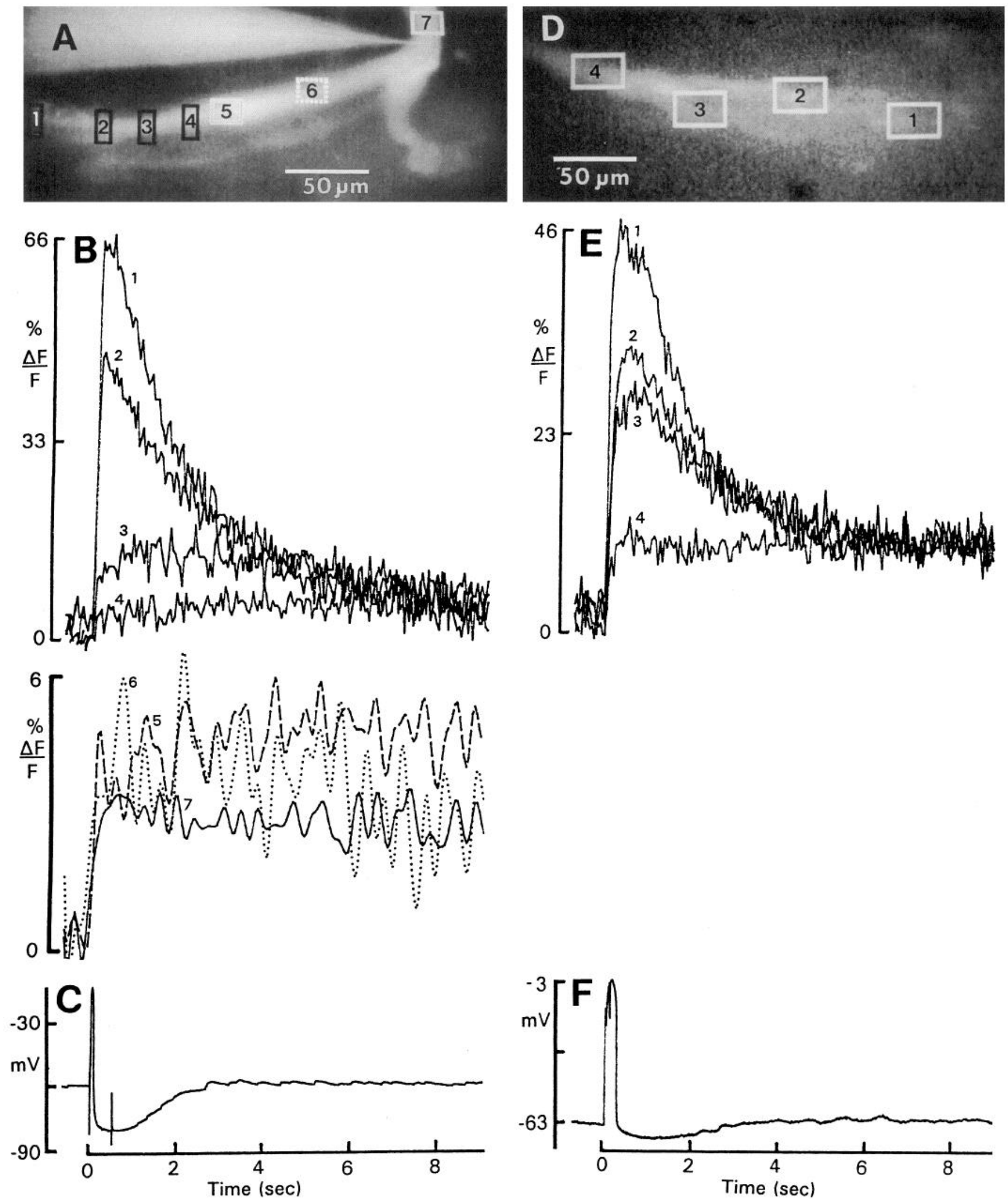

Figure 3. Change in $\left[\mathrm{Ca}^{2+}\right]_{i}$ in response to a calcium-dependent action potential generated in two different arbors. $A$ and $D$, Digital photographs of Fura-2-filled arbors to show areas of optical recording corresponding to numbered traces. $B$ and $E$, Change in the Fura-2 fluorescence at seven $(B)$ and four $(E)$ locations along the arbors in response to an action potential. $C$ and $F$, Intracellular recording of action potentials set up by 500 msec $(C)$ or $100 \mathrm{msec}(F)$ pulses of depolarizing current in the presence of external TEA $(10 \mathrm{~mm})$. The vertical lines are stimulus artifacts. For $E$, five sweeps delivered at $20 \mathrm{sec}$ intervals were averaged for the voltage and optical recordings; $B$ is from a single sweep. Note that in trace 3 of $B$ the $\left[\mathrm{Ca}^{2+}\right]_{i}$ rose abruptly during the action potential even in the primary branch and continued to rise to a later peak as $\mathrm{Ca}^{2+}$ from the tips diffused retrogradely. $A-C$ are from the same preparation as in Figure 1 and Figure $2, A$ and $C$. 


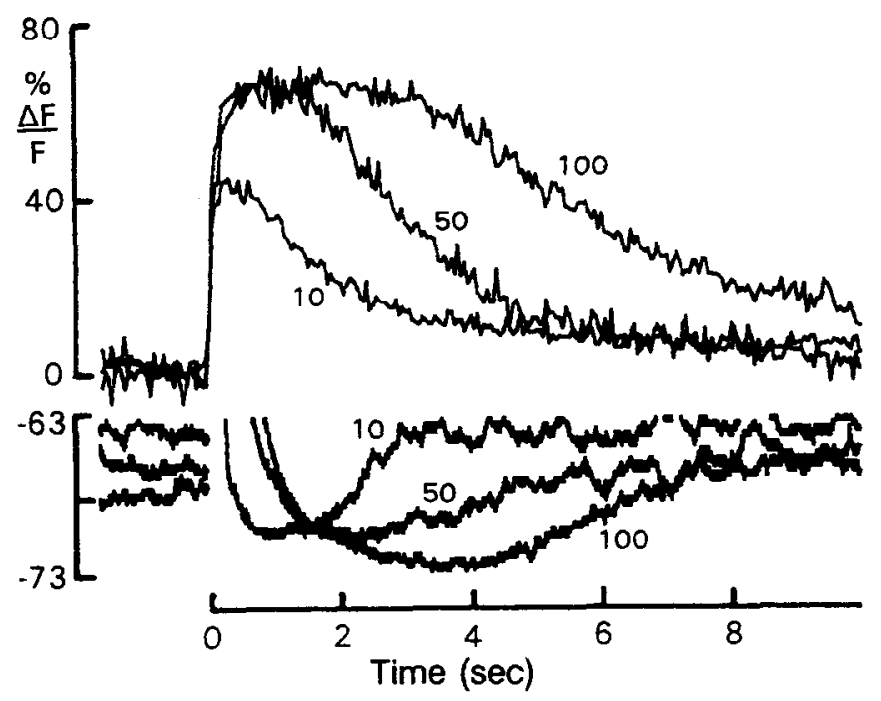

Figure 4. Correspondence between the time course of the undershoot of the $\mathrm{Ca}^{2+}$-dependent action potential and the Fura-2 signal. Fura-2 signals (upper set of traces) and voltage undershoots (lower set of traces) were recorded from the terminal region of the same preparation superfused with 10,50 , and $100 \mathrm{~mm}$ TEA (labels on traces). The three action potentials (depolarizing phase off scale) increased in duration with increasing [TEA], resulting in increasing $\mathrm{Ca}^{2+}$ entry and an undershoot of increasing duration.

Threshold voltage for the increase in $\left[\mathrm{Ca}^{2+}\right]_{\mathrm{i}}$. We stepped the membrane potential from a holding value to determine the level where we could observe the smallest detectable change in the $\left[\mathrm{Ca}^{2+}\right]_{i}$ (Fig. 5). In Figure 5A, the membrane was depolarized to several levels from a holding potential below threshold (holding potential was considered below threshold if hyperpolarizations from that value led to no change in the Fura-2 signal, i.e., no decrease in $\left[\mathrm{Ca}^{2+}\right]_{i}$ ). In the experiment shown in Figure $5 A$, both the large and the small voltage pulses evoked a change in the Fura-2 signal when the voltage reached about $-58 \mathrm{mV}( \pm 5$ $\mathrm{mV}$ ). Thresholds determined in this manner for two other cells were $-60 \mathrm{mV}( \pm 2 \mathrm{mV})$ and $-57 \mathrm{mV}( \pm 2 \mathrm{mV})$.

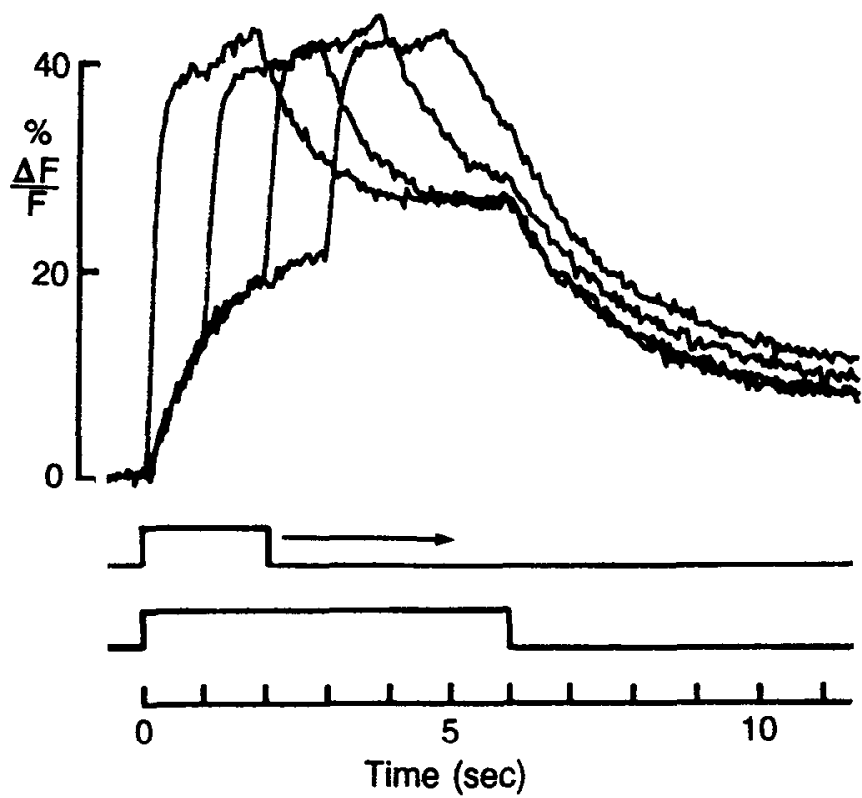

Figure 6. $\left[\mathrm{Ca}^{2+}\right]$, responses to two summed pulses provide evidence for steady entry of $\mathrm{Ca}^{2+}$ during depolarization. The base Fura-2 signal was evoked by a $6 \mathrm{sec}$ depolarizing pulse (lowermost indicator trace), and a second signal was evoked by a $2 \mathrm{sec}$ test pulse of equal amplitude (upper indicator trace) added on the $6 \mathrm{sec}$ trace. The test pulse was delivered at $0 \mathrm{sec}$ (position of indicator trace), and then 1,2, and $3 \mathrm{sec}$ (increasing delay represented by arrow) after the onset of the $6 \mathrm{sec}$ pulse. Responses to all four sets of stimuli are superimposed. The similar kinetics and amplitudes of the responses to each test pulse argue that there is no inactivation of the $\mathrm{Ca}^{2+}$ current during the $6 \mathrm{sec}$ pulse.

When a cell was maintained depolarized above threshold for seconds to minutes, the end of the pulse led to a decrease in $\left[\mathrm{Ca}^{2+}\right]_{i}$. Figure $5 B$ shows the $\left[\mathrm{Ca}^{2+}\right]_{i}$ change at the offset of three sustained, depolarizing pulses, one well above $(-51 \mathrm{mV})$, one slightly above $(-58 \mathrm{mV})$, and one below threshold $(-68 \mathrm{mV})$. The agreement between threshold values determined at pulse onset and offset shows that there was no substantial change in threshold during the time that the cell was held depolarized.

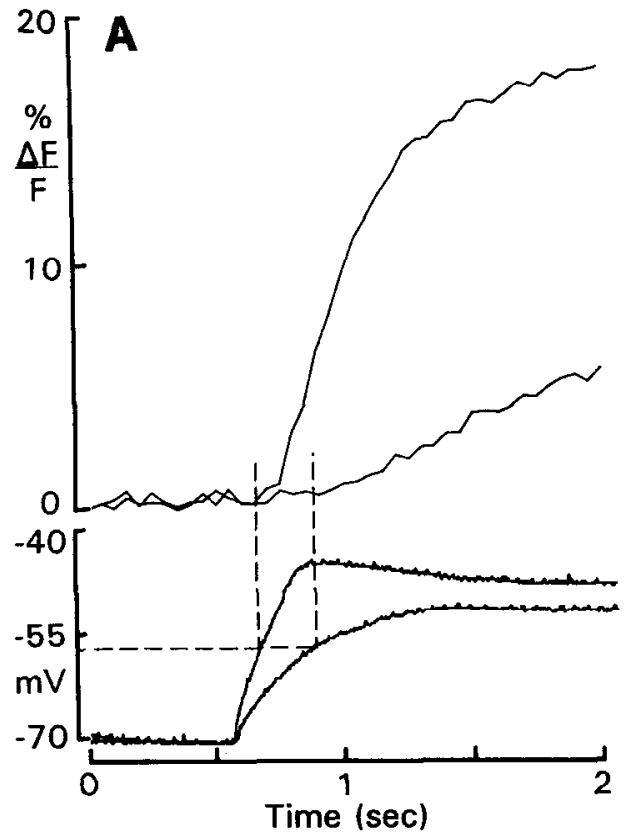

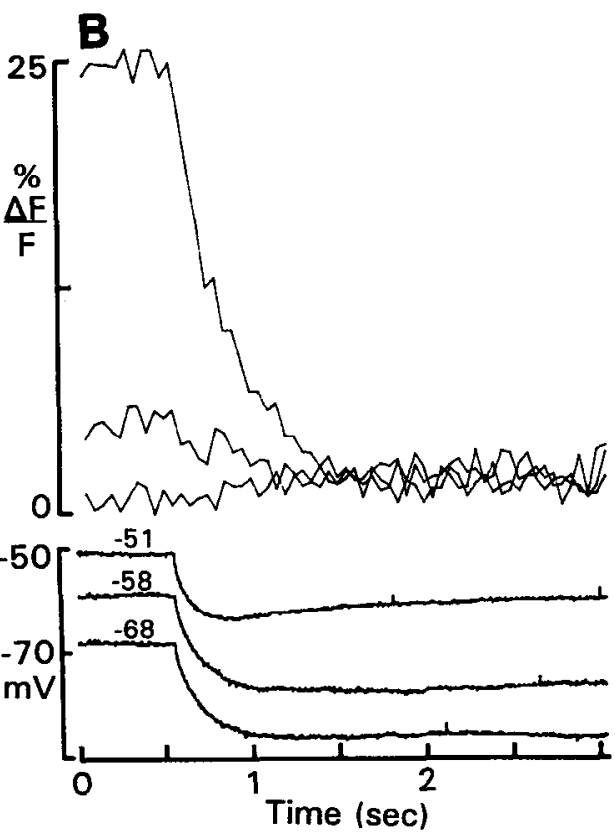

Figure 5. Threshold voltages for Fura-2 signals measured at the onset and offset of depolarizing current pulses. $A$, Changes in $\Delta F / F$ (above) during two voltage depolarizations caused by injected current pulses (below) of different amplitudes. Broken lines indicate that the onset of the $\mathrm{Ca}^{2+}$ signal is -58 $\mathrm{mV}( \pm 5 \mathrm{mV}) . B$, Change in $\Delta F / F$ (above) at the offset of three prolonged (minutes) current pulses (below) that depolarized the cell to the values indicated above each trace (different cell). The smallest detectable change in the Fura-2 signal occurred at the offset of the pulse holding at $-58 \mathrm{mV}$ (middle traces). 
Increases in $\left.\mathrm{CCa}^{2+}\right]_{\mathrm{i}}$ in response to two superimposed depolarizing pulses. We delivered a $2 \mathrm{sec}$ (Fig. 6, top indicator trace) depolarizing test pulse to the arbor at various times $(0,1,2$, and $3 \mathrm{sec}$ ) after it had been depolarized with a longer pulse. The rise time and peak amplitude of the $\mathrm{Ca}^{2+}$ signal (upper traces) in the tips of the arbor were the same in response to each test pulse regardless of when it was delivered. These results and the preceding threshold measurements are consistent with observations that the macroscopic $\mathrm{Ca}^{2+}$ current in the terminals is noninactivating (Hayashi and Stuart, 1984, 1993).

\section{Discussion}

The experiments in this article address four issues: (1) the location of voltage-dependent calcium entry in the photoreceptor terminal region, (2) the properties of the $\mathrm{Ca}^{2+}$ channels responsible for this $\mathrm{Ca}^{2+}$ entry, (3) the mechanism by which $\mathrm{Ca}^{2+}$ is removed from the release sites following voltage-dependent entry, and (4) the relationship between $\left[\mathrm{Ca}^{2+}\right]_{i}$ and transmitter release at this synapse.

Location of calcium entry. The spatial distribution of the voltage-dependent Fura- 2 transients confirmed the results of Stockbridge and Ross (1984) that $\mathrm{Ca}^{2+}$ entry was predominantly at the tips of the terminal region. The higher resolution of the present experiments showed that the region of entry was precisely located where the arbor divides into the processes contacting the second-order cells (Schnapp and Stuart, 1983). Thus, at this tonically releasing presynaptic terminal, $\mathrm{Ca}^{2+}$ channels are concentrated in the region of transmitter release as they are at the neuromuscular junction (Robitaille et al., 1990; Cohen et al., 1991) or squid giant synapse (Augustine et al., 1989) where the presynaptic terminal is invaded by action potentials. Localization of $\mathrm{Ca}^{2+}$ entry into the terminal region has also recently been reported for monkey cones (MacLeish and O'Brian, 1992).

The spatial resolution of our technique was not adequate to determine if there is a punctate distribution of $\mathrm{Ca}^{2+}$ channels that might correspond to active zones (Robitaille et al., 1990; Cohen et al., 1991), nor do we know the spacing of the active zones along the arbor. At phasic synapses, the localization of $\mathrm{Ca}^{2+}$ channels at active zones is critical for rapid synaptic transmission. In particular, the measured delay of less than $200 \mu \mathrm{sec}$ between the entry of $\mathrm{Ca}^{2+}$ and the postsynaptic response at the squid synapse requires that the $\mathrm{Ca}^{2+}$ channels be within microns of the release sites (Llinas et al., 1981). However, at the photoreceptor synapse, which ordinarily experiences changes in potential an order of magnitude slower, this close overlap of $\mathrm{Ca}^{2+}$ channels and release sites may not be necessary. Indeed, these experiments demonstrate that there are significant numbers of extrasynaptic $\mathrm{Ca}^{2+}$ channels, since clear, but small, $\mathrm{Ca}^{2+}$ transients were detected upstream of the terminal region when a $\mathrm{Ca}^{2+}$-dependent action potential was evoked.

Properties of the $\mathrm{Ca}^{2+}$ channels. We found that there was a clear threshold for $\mathrm{Ca}^{2+}$ entry near $-60 \mathrm{mV}$, a value that did not change with prolonged depolarization (Fig. 5). This threshold potential is approximately the same as determined by voltage-clamp experiments in the same preparation (Hayashi and Stuart, 1984, 1993). At the squid giant synapse, the threshold for presynaptic $\mathrm{Ca}^{2+}$ entry also is near $-60 \mathrm{mV}$ (Augustine et al., 1985). Small (2-3 mV) depolarizations from this value can cause transmitter release as long as these depolarizations are prolonged (Charlton and Atwood, 1977). Thus, with respect to threshold for $\mathrm{Ca}^{2+}$ entry, there may be no essential difference between the $\mathrm{Ca}^{2+}$ channels at the two kinds of synapses. However, the presynaptic voltage at which a fast and large postsyn- aptic response is generated appears to be different in the two preparations. Step depolarizations of the barnacle photoreceptor terminals from $-60 \mathrm{mV}$ to only $-50 \mathrm{mV}$ evoke a saturating postsynaptic response (Hayashi et al., 1985), whereas at the squid synapse a significant postsynaptic current does not appear until the voltage is stepped to $-40 \mathrm{mV}$ (Augustine et al., 1985). This difference may be meaningful: a higher threshold at synapses invaded by action potentials would prevent small membrane potential fluctuations from evoking unwanted release of transmitter, whereas a lower threshold at the tonically releasing synapse would allow the transfer of small graded potentials close to the dark resting potential.

These experiments also confirm previous observations that the $\mathrm{Ca}^{2+}$ channels in these terminals do not inactivate over a time course of seconds (Hayashi and Stuart, 1984, 1993). We found that $\mathrm{Ca}^{2+}$ continued to enter during maintained depolarization and that there was no change in the amplitude of the $\left[\mathrm{Ca}^{2+}\right]_{i}$ transients for pulses coming at different times on top of a long depolarizing pulse (Fig. 6). $\mathrm{Ca}^{2+}$ channels in rods, cones, and hair cells (Corcy ct al., 1984; Barncs and Hille, 1989; Roberts et al., 1990), other nonspiking cells, also do not inactivate, but lack of inactivation has also been found at presynaptic terminals invaded by action potentials (Lindgren and Moore, 1989; Charlton and Augustine, 1990).

Mechanism of $\mathrm{Ca}^{2+}$ removal. Several experiments indicate that following the entry of $\mathrm{Ca}^{2+}$ into the processes containing the release sites, the major removal mechanism is diffusion away from the terminals toward the axon. The time courses of the transients along the arbor are consistent with this mechanism. In the tips of the terminal, the $\left[\mathrm{Ca}^{2+}\right]_{i}$ rises immediately following the onset of a depolarizing pulse and begins to decline immediately following its termination (Fig. 1). In the primary processes, however, $\left[\mathrm{Ca}^{2+}\right]_{i}$ rises more slowly and with a delay following the start of the pulse. At the end of the pulse, $\left[\mathrm{Ca}^{2+}\right]_{i}$ continues to rise at these extrasynaptic locations, with a later time to pcak at greatcr distances from the tips. These qualitative observations are supported by a computer model of the terminal region (Fig. 7). This simulation used a version of the program CABLE, developed by M. Hines and J. W. Moore (Hines, 1989). In the model, we assumed that $\mathrm{Ca}^{2+}$ entered the terminal in a voltage-dependent manner and spread radially or axially by buffered diffusion. Dimensions were taken from typical terminal arbors. With reasonable adjustment of parameters (see Fig. 7 caption), we found that we could qualitatively reproduce the time courses of $\left[\mathrm{Ca}^{2+}\right]_{i}$ in both the terminal and axonal regions. The model also generated a stable gradient of $\left[\mathrm{Ca}^{2+}\right]_{i}$ in the cell at depolarized potentials when $\mathrm{Ca}^{2+}$ entered continuously into the terminal region (not illustrated). This gradient was similar to the one observed experimentally (Fig. 2).

Further support for the importance of diffusion is that suppression of a possible $\mathrm{Na}^{+} / \mathrm{Ca}^{2+}$ exchanger by removal of $\left[\mathrm{Na}^{+}\right]_{0}$ had no detectable effect on the removal rate. Ultimately, membrane-dependent mechanisms must be important in maintaining $\left[\mathrm{Ca}^{2+}\right]_{i}$ homeostasis in the cell. However, they probably work by removing $\mathrm{Ca}^{2+}$ over a large area of cell membrane rather than pumping it out only through the membrane in the region where it entered.

$\left[\mathrm{Ca}^{2+}\right]_{\mathrm{i}}$ and transmitter release. The results of these experiments bear on the effort to determine the relationship between $\left[\mathrm{Ca}^{2+}\right]_{i}$ at the release sites and the postsynaptic response. Our time-dependent and steady-state Fura- 2 measurements suggest that the mean $\left[\mathrm{Ca}^{2+}\right]_{i}$ in the terminal region increases smoothly from resting levels around $100 \mathrm{~nm}$ to values below $1 \mu \mathrm{M}$ at 

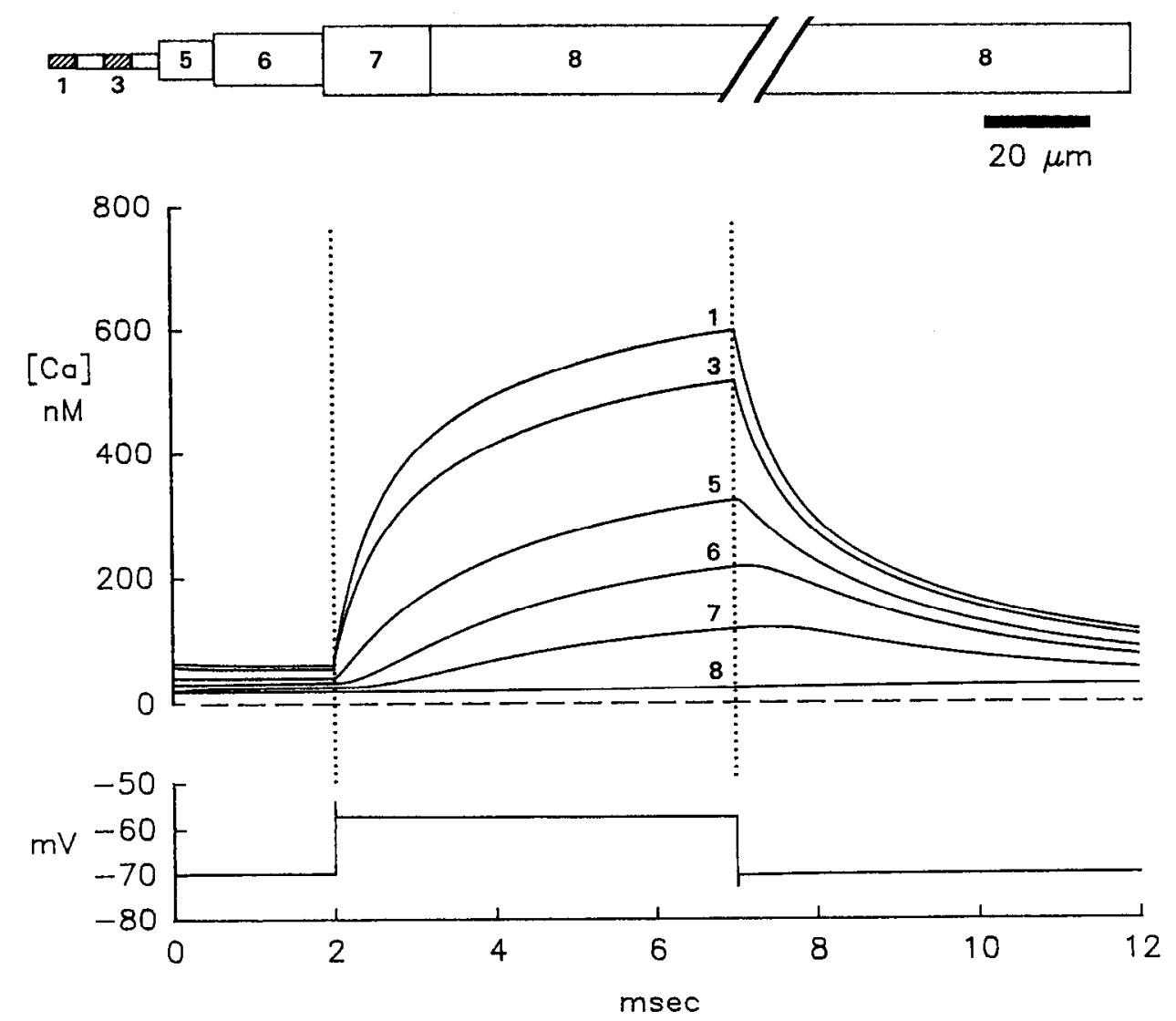

Figure 7. Model of $\mathrm{Ca}^{2+}$ diffusion through the photoreceptor arbor. Top, Diagram of the modeled terminal. The morphology of the terminal is represented by a series of eight cylindrical compartments connected end to end. The four leftmost segments $(1-4)$ are each $2 \mu \mathrm{m}$ in diameter and $5 \mu \mathrm{m}$ long and represent the tips of the photoreceptor arbor. Segments $5(8 \times 10 \mu \mathrm{m}), 6(10 \times 20 \mu \mathrm{m})$, and $7(15 \times 20 \mu \mathrm{m})$ represent the secondary and primary photoreceptor processes by a transition in diameter from the 2 - $\mu \mathrm{m}$-diameter tips to the 15 - $\mu \mathrm{m}$-diameter axon. Segment $8(15 \times 180$ $\mu \mathrm{m})$ represents only the proximal end of a normally $10-\mathrm{mm}$-long photoreceptor axon. The diameters and lengths of the sections were based on data from electron microscopy (Schnapp and Stuart, 1983) and from images of the Fura-2-filled terminals in these experiments and procion yellowfilled terminals (Hudspeth and Stuart, 1977; Stockbridge and Ross, 1984). Each of the segments contained Hodgkin-Huxley-type $\mathrm{K}^{+}$channels and calcium-activated $\mathrm{K}^{+}$channels but no $\mathrm{Na}^{+}$channels (Hudspeth et al., 1977). Noninactivating Ca ${ }^{2+}$ channels were placed in only the four 2- $\mu \mathrm{m}-$ diameter tip segments. No pumps or $\mathrm{Na}^{+} / \mathrm{Ca}^{2+}$ exchange was introduced into any of the segments. Longitudinal $\mathrm{Ca}^{2+}$ diffusion was allowed between adjacent sections; thus, $\left[\mathrm{Ca}^{2+}\right]_{i}$ increases in segments $5-8$ are from diffusion of $\mathrm{Ca}^{2+}$ away from the tip segments. The calcium diffusion model provided with CABLE (Hines, 1989) was used with the ratio of bound to free calcium $(\beta)$ set to 100 . Bottom, $\left[\mathrm{Ca}^{2+}\right]_{i}$ in individual segments. $\left[\mathrm{Ca}^{2+}\right]_{i}$ is shown for two of the four tip segments and for segments $5-8$. Numbers above each trace correspond to the numbers in the diagram above. During a $5 \mathrm{sec}$ depolarizing current pulse to segment 8 , there was a rapid rise in $\left[\mathrm{Ca}^{2+}\right]_{i}$ in the tip sections $(1,3)$ where Ca directly entered the cell. The $\left[\mathrm{Ca}^{2+}\right]_{i}$ there neared a plateau and abruptly fell at the end of the pulse. In each of the remaining segments, where [Ca $\left.{ }^{2+}\right]_{i}$ accumulation was due to diffusion, the $\left[\mathrm{Ca}^{2+}\right]_{i}$ rise was delayed, was slower, and reached a lower level than in the tips. $\left[\mathrm{Ca}^{2+}\right]_{i}$ continued to rise due to diffusion in segments $5-7$, for a short period at the end of the pulse before it declined.

depolarized potentials that occur during steady illumination of the photoreceptor. Also, the experiments of Hayashi et al. (1985) show that the postsynaptic response begins at about the same presynaptic membrane potential that, in the present experiments, is the threshold for $\mathrm{Ca}^{2+}$ entry. Together, these data indicate that a mean $\left[\mathrm{Ca}^{2+}\right]_{i}$ in the submicromolar range can cause significant transmitter relcasc. What is not clcar is whether the mean concentration also represents the concentration at the release sites. Both the short time for radial $\mathrm{Ca}^{2+}$ diffusion to reach equilibrium (Stockbridge and Ross, 1984) and the correspondence between the time course of the $\mathrm{Ca}^{2+}$ spike undershoot and the time course of the associated $\mathrm{Ca}^{2+}$ transients (Fig. 4) suggest that the mean $\left[\mathrm{Ca}^{2+}\right]_{i}$ in the volume of the terminal is close to the average $\left[\mathrm{Ca}^{2}\right]_{i}$ just under the membrane. However, it is possible that there are zones of very high $\left[\mathrm{Ca}^{2+}\right]_{i}$ near the mouth of $\mathrm{Ca}^{2+}$ channels and the $\mathrm{Ca}^{2+}$-sensitive sites triggering release are localized to these zones, as has been suggested for the neuromuscular junction (Robitaille et al., 1990), squid synapse (Adler et al., 1991), and hair cell synapse (Roberts et al., 1990). In this case, the mean $\left[\mathrm{Ca}^{2+}\right]_{i}$ will not indicate the concentration affecting release (Swandulla et al., 1991). The synapses mentioned above, however, are all synapses where transmitter release tracks rapid presynaptic voltage changes. The slower kinetics of this photoreceptor synapse frees the release sites from the requirement of close proximity to the $\mathrm{Ca}^{2+}$ channels. Consequently, it may be possible to position a greater number of vesicles in the docking area to subserve the continuous release of transmitter. However, until this spatial relationship is determined we cannot draw strong conclusions about the $\left[\mathrm{Ca}^{2+}\right]_{i}$ needed for transmitter release.

\section{References}

Adler EM, Augustine GJ, Duffy SN, Charlton MP (1991) Alien intracellular calcium chelators attenuate neurotransmitter release at the squid giant synapse. J Neurosci 11:1496-1507. 
Attwell D (1986) The Sharpey-Schafer Lecture: ion channels and signal processing in the outer retina. Q J Exp Physiol 71:497-536.

Augustine GJ, Charlton MP, Smith SJ (1985) Calcium entry into voltage-clamped presynaptic terminals of squid. J Physiol (Lond) 367 : 143-162.

Augustine GJ, Buchanan JA, Charlton MP, Osses LR, Smith SJ (1989) Fingering the trigger for neurotransmitter secretion: studies on the calcium channels of squid giant presynaptic terminals. In: Secretion and its control (Armstrong CM, Oxford GS, eds), pp 203-223. New York: Rockefeller UP.

Barnes S, Hille B (1989) Ionic channels of the inner segment of tiger salamander cone photoreceptors. J Gen Physiol 94:719-743.

Baylor SM, Hollingworth S (1988) Fura-2 $\mathrm{Ca}^{2+}$ transients in frog skeletal muscle fibres. J Physiol (Lond) 403:151-192.

Blumenfeld H, Spira ME, Kandel ER, Siegelbaum SA (1990) Facilitory and inhibitory transmitters modulate calcium influx during action potentials in Aplysia sensory neurons. Neuron 5:487-499.

Callaway JC, Stuart AF (1989) Biochemical and physiological evidence that histamine is the transmitter of barnacle photoreceptors. Vis Neurosci 3:311-325.

Callaway JC, Lasser-Ross N, Stuart $\Lambda E$, Ross WN (1990) Calcium dynamics in the presynaptic terminals of barnacle photoreceptors. Biol Bull 179:228-229.

Cervetto L, Piccolino M (1974) Synaptic transmission between photoreceptors and horizontal cells in the turtle retina. Science 183:417419.

Charlton MP, Atwood HL (1977) Slow release of transmitter at the squid giant synapse. Neurosci Lett 5:165-169.

Charlton MP, Augustine GJ (1990) Classification of presynaptic calcium channels at the squid giant synapse: neither T-, L-, nor $\mathrm{N}$-type. Brain Res 525:133-139.

Charlton MP, Smith SJ, Zucker RS (1982) Role of presynaptic calcium ions and channels in synaptic facilitation and depression at the squid giant synapse. J Physiol (Lond) 323:173-193.

Cohen MW, Jones OT, Angelides KJ (1991) Distribution of $\mathrm{Ca}^{2+}$ channels on frog motor nerve terminals revealed by fluorescent $\omega$-conotoxin. J Neurosci 11:1032-1039.

Connor JA (1986) Digital imaging of free calcium changes and of spatial gradients in growing processes in single mammalian central nervous system cells. Proc Natl Acad Sci USA 83:6179-6183.

Corey DP, Dubinsky JM, Schwartz EA (1984) The calcium current in inner segments of rods from the salamander (Ambystoma tigrinum) retina. J Physiol (Lond) 354:557-575.

Edgington DR, Stuart AE (1979) Calcium channels in the high resistivity axonal membrane of photoreceptors of the giant barnacle. $J$ Physiol (Lond) 294:433-445.

Edgington DR, Stuart AE (1981) Properties of tetraethylammonium ion-resistant $\mathrm{K}^{+}$channels in the photoreceptor membrane of the giant barnacle. J Gen Physiol 77:629-646.

Edgington DR, Stuart AE (1992) Responses to light generated in the presynaptic terminals of barnacle photoreceptors. Biomed Res 12[Suppl 2]:237-238.

Grynkiewicz G, Poenie M, Tsien RY (1985) A new generation of $\mathrm{Ca}^{2+}$ indicators with greatly improved fluorescence properties. J Biol Chem 260:3440-3450.

Hayashi JH, Stuart AE (1984) Calcium currents in the presynaptic terminal of the barnacle photoreceptor. Soc Neurosci Abstr 10:194.

Hayashi JH, Stuart AE (1993) Currents in the presynaptic terminal arbors of barnacle photoreceptors. Vis Neurosci 10 , in press.

Hayashi JH, Moore JW, Stuart AE (1985) Adaptation in the input/ output relation of the synapse made by the barnacle's photoreceptor. J Physiol (Lond) 368:179-195.

Hines M (1989) A program for simulation of nerve equations with branching geometry. Int J Biomed Comput 24:55-68.

Hudspeth AJ, Stuart AE (1977) Morphology and responses to light of the somata, axons, and terminal regions of individual photoreceptors of the giant barnacle. J Physiol (Lond) 272:1-23.

Hudspeth AJ, Poo MM, Stuart AE (1977) Passive signal propagation and membrane properties in median photoreceptors of the giant barnacle. J Physiol (Lond) 272:25-43.

Lasser-Ross N, Callaway JC, Stuart AE, Ross WN (1991a) Calcium dynamics in the presynaptic terminal of barnacle photoreceptors. Ann NY Acad Sci 635:475-476.

Lasser-Ross N, Miyakawa H, Lev-Ram V, Young SR, Ross WN (1991b) High time resolution fluorescence imaging with a CCD camera. J Neurosci Methods 36:253-261.

Lev-Ram V, Miyakawa H, Lasser-Ross N, Ross WN (1992) Calcium transients in cerebellar Purkinje neurons evoked by intracellular stimulation. J Neurophysiol 68:1167-1177.

Lindgren CA, Moore JW (1989) Identification of ionic currents at presynaptic nerve endings of the lizard. J Physiol (Lond) 414:201222.

Llinas R, Steinberg IZ, Walton K (1981) Presynaptic calcium currents in squid giant synapse. Biophys J 33:289-322.

MacLeish PR, O'Brian EV (1992) Fura-2 imaging of calcium in solitary monkey cones. Invest Ophthalmol Vis Sci [Suppl] 33:753.

Roberts WM, Jacobs RA, Hudspeth AJ (1990) Colocalization of ion channels involved in frequency selectivity and synaptic transmission at presynaptic active zones of hair cells. J Neurosci 10:3664-3684.

Robitaille R, Adler EM, Charlton MP (1990) Strategic location of calcium channels at transmitter release sites of frog neuromuscular synapses. Neuron 5:773-779.

Ross WN, Stuart AE (1978) Voltage sensitive calcium channels in the presynaptic terminals of a decrementally conducting photoreceptor J Physiol (Lond) 274:173-191.

Schnapp BJ, Stuart AE (1983) Synaptic contacts between physiologically identified neurons in the visual system of the barnacle. J Neurosci 3:1100-1115.

Smith SJ, Augustine GJ (1988) Calcium ions, active zones and synaptic transmitter release. Trends Neurosci 11:458-464.

Stockbridge NL, Ross WN (1984) Localized $\mathrm{Ca}^{2+}$ and calcium-activated potassium conductances in terminals of a barnacle photoreceptor. Nature 309:266-268.

Stuart AE, Hayashi JH, Moore JW, Davis RE (1986) Currents in the synaptic terminals of barnacle photoreceptors. In: Calcium, neuronal function and transmitter release (Rahamimoff R, Katz B, eds), pp 443-455. New York: Nijhoff.

Stuart AE, Callaway, JC, Lasser-Ross N, Ross WN (1991) Calcium dynamics in the presynaptic terminals of barnacle photorcceptors. Invest Ophthalmol Vis Sci [Suppl] 32:672.

Swandulla D, Hans M, Zipser K, Augustine GJ (1991) Role of residual calcium in synaptic depression and posttetanic potentiation: fast and slow calcium signalling in nerve terminals. Neuron 7:915-926.

Thomas P, Suprenant A, Almers W (1990) Cytosolic Ca, exocytosis, and endocytosis in single melanotrophs of rat pituitary. Neuron 5:723733.

Verhage M, McMahon HT, Ghijsen WEJM, Boomsma F, Scholten G, Wiegant VM, Nicholls DG (1991) Differential release of amino acids, neuropeptides, and catecholamines from isolated nerve terminals. Neuron 6:517-524. 